\title{
Sweet potato little leaf strain V4 phytoplasma associated with snake bean in the Northern Territory, Australia
}

\author{
L. T. T. Tran-Nguyen • S. H. Smith • J. R. Liberato
}

Received: 29 January 2012 / Accepted: 30 August 2012 / Published online: 4 October 2012

(C) Australasian Plant Pathology Society Inc. 2012

\begin{abstract}
Sweet potato little leaf strain V4 phytoplasma (SPLL-V4) was found to be associated with 12-week old snake bean plants (Vigna unguiculata ssp. sesquipedalis) from a block with 890 plants in Lambells Lagoon, Northern Territory. Symptoms included witches' broom, big bud, phyllody and little leaf. There was a $19.9 \%$ incidence of symptoms on 366 plants assessed. The same phytoplasma was also detected from a single plant of Phyllanthus amarus with witches' broom symptoms growing near the snake bean plants. The SPLL-V4 phytoplasma was identified based upon the 16S ribosomal RNA gene and intergenic spacer region nucleotide sequence and restriction fragment length polymorphism.
\end{abstract}

Keywords "Candidatus Phytoplasma aurantifolia" · Vigna unguiculata ssp. sesquipedalis

Snake bean (Vigna unguiculata ssp. sesquipedalis) has been cultivated commercially in the Northern Territory (NT) since the early 1990s. Current production is approximately $537 \mathrm{t}$, valued at AUD\$2.8 million (Department of Primary Industry and Fisheries 2010). Crops are grown predominantly in the dry season from May to September, supplying markets in population centres in the Eastern states of Australia when local production of beans ceases due to low autumn and winter temperatures. Beans are grown on $3 \mathrm{~m}$ high trellis (net) approximately $2 \mathrm{~m}$ apart. They are hand harvested, cooled and marketed in $10 \mathrm{~kg}$ boxes. Most snake bean consumers in Australia are of Asian origin and most growers in the NT are of Vietnamese or Cambodian ethnicity.

L. T. T. Tran-Nguyen $(\bowtie) \cdot$ S. H. Smith $\cdot$ J. R. Liberato

Department of Primary Industry and Fisheries,

Plant Industries Group,

GPO Box 3000, Darwin, NT 0801, Australia

e-mail: lucy.tran-nguyen@nt.gov.au
In December 2010, 12-week old snake beans plants grown in a block of 890 (approximate) plants at Lambells Lagoon, NT, were observed with phytoplasma-like symptoms, namely reduced leaf size (little leaf), big bud, phyllody, deformation and proliferation of stems, leaves and flowers (witches' broom) (Fig. 1). The disease incidence was assessed on 366 plants and determined to be $19.9 \%$. Phyllanthus amarus (stonebreaker) growing near the snake bean plants was also showing witches' broom symptoms.

A sample of symptomatic snake bean plants and the Phyllanthus amarus plant was collected. DNA extractions were conducted using the DNeasy Plant kit (Qiagen, Australia) following the manufacturer's instructions. The phytoplasma 16S rRNA, intergenic spacer region and the start of the 23S rRNA gene were amplified with the polymerase chain reaction (PCR) using universal primers: fP1 (Deng and Hiruki 1991) and rP7 (Schneider et al. 1995). The $1,800 \mathrm{bp}$ PCR product was sequenced and bioinformatic analyses were conducted using the Geneious Pro software (Drummond et al. 2011). Genetic relatedness between the snake bean and Phyllanthus amarus phytoplasmas were determined by restriction fragment length polymorphism (RFLP) using the restriction enzymes, Alu I and Rsa I (Promega, Australia), following the manufacturer's instructions. The digestion patterns were compared with reference samples tomato big bud (TBB), sweet potato little leaf (SPLL) and SPLL strain-V4 (SPLL-V4) phytoplasmas. The snake bean and Phyllanthus amarus phytoplasmas were indistinguishable from the SPLL-V4 phytoplasma (data not shown).

The phylogenetic dendrogram of the 16S rRNA gene sequences from 25 phytoplasmas showed that phytoplasma from snake bean grouped with the SPLL phytoplasma previously detected in snake beans and tomatoes in Western Australia (Saqib et al. 2006), GenBank accession numbers DQ375777 and DQ375778, respectively (Fig. 2). They all clustered together with the TBB phytoplasma (GenBank 
Fig. 1 Snake bean plants associated with sweet potato little leaf strain V4 phytoplasma in the Northern Territory, in December 2010 (images by J.R. Liberato)
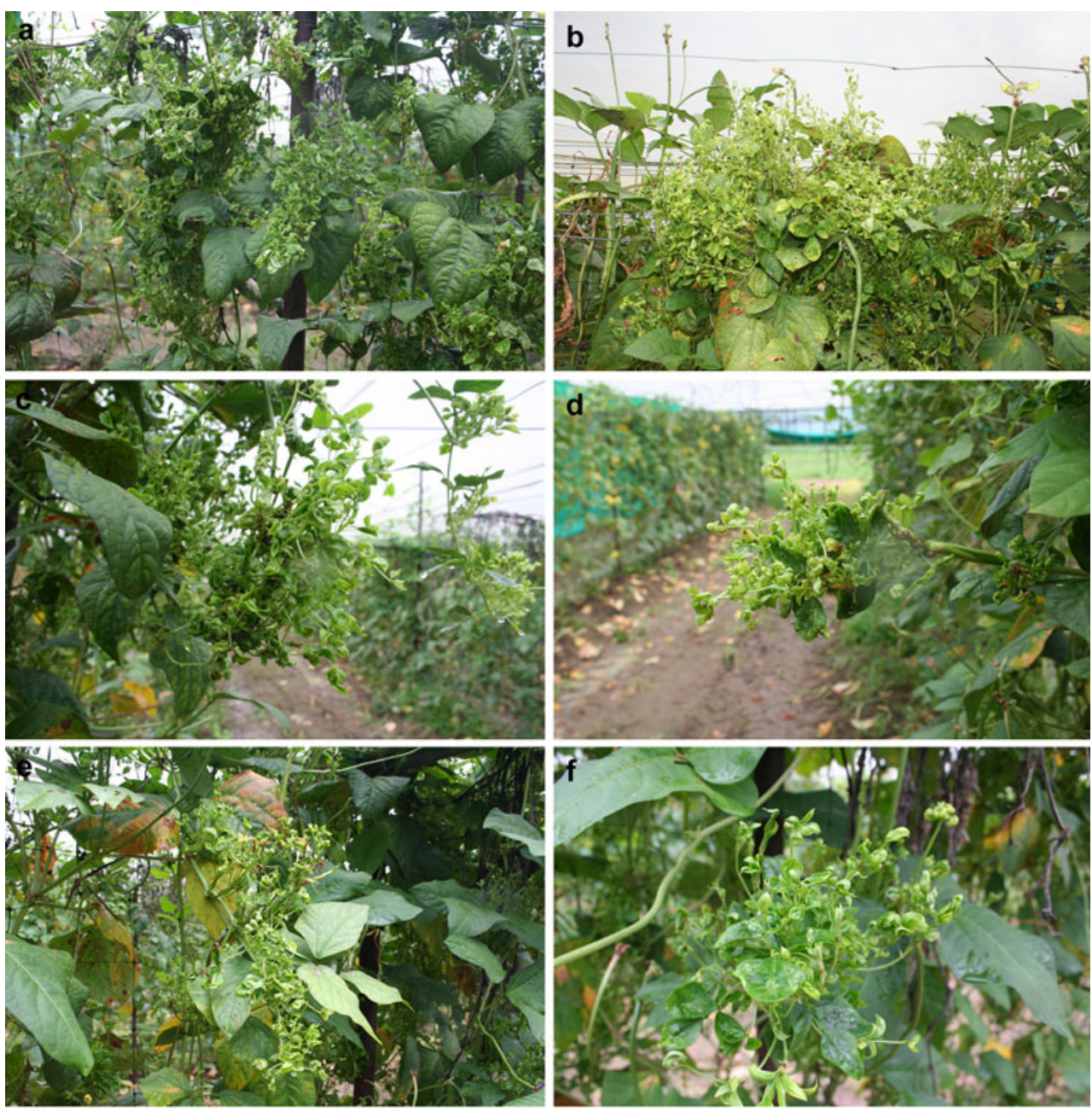

accession number EF193359) and SPLL-V4 (GenBank accession number AJ289193). TBB and SPLL-V4 are closely related phytoplasmas within the "Candidatus Phytoplasma aurantifolia" 16S rII group (IRPCM 2004). The 16S rRNA gene nucleotide sequence from the phytoplasma in snake bean was submitted to GenBank and assigned the accession number JQ067649. A sub-sample of diseased snake bean associated with the SPLL-V4 phytoplasma was deposited in the Northern Territory Plant Pathology Herbarium (DNAP 4610).

Streten and Gibb (2006) listed 28 genera of plants as hosts of the SPLL-V4 phytoplasma in Australia. In the NT, SPLL was reported on Ipomoea batatas (sweet potato) (Gibb et al. 1995, Davis et al. 1997), Carica papaya (papaya) (De La Rue et al. 1999), Cleoma viscosa (mustard bush), Crotalaria brevis (rattlepod), Indigofera colutea (sticky indigo), Phyllanthus maderaspanatus and Senna obtusifolia (sicklepod) (Schneider et al. 1999); and SPLLV4 was reported on Aeschynomene americana (American jointvetch), Alysicarpus vaginalis (alyce clover), Arachis hypogaea (peanut), Centrosema pascuorum (cavalcade),
Crotalaria goreensis (gambia pea), Medicago sativa (lucerne), Mitracarpus hirtus (tropical girdlepod), Rhynchosia minima (rhynchosia), Sesamum indicum (sesame), Vigna radiata (mung bean) (Wilson et al. 2001) and C. papaya (Padovan and Gibb 2001).

Phytoplasma are non-culturable, one-celled, wall-less prokaryotes (class Mollicutes) that replicate in insects and plants, where they are phloem-limited. Phytoplasmas are naturally transmitted by phloem-feeding insects (Hogenhout et al. 2008). More than three quarters of the insect vectors of phytoplasmas belong to the subfamily Deltocephalinae (Hemiptera: Cicadellidae, leafhoppers) (Weintraub and Beanland 2006). There is evidence that the leafhoppers, Orosius spp., are vectors of SPLL. Padovan \& Gibb (2001) found SPLL-V4 phytoplasmas in the bodies of a combined sample of $O$. argentatus and $O$. lotophagorum. Based on the number and origin of specimens of $O$. argentatus (common brown leafhopper) in the Australian collections (APPD 2011), this leafhopper is widely distributed throughout Australia and is the vector of several phytoplasmas in Australia (Hill 1943, referred as Thamnotettix 


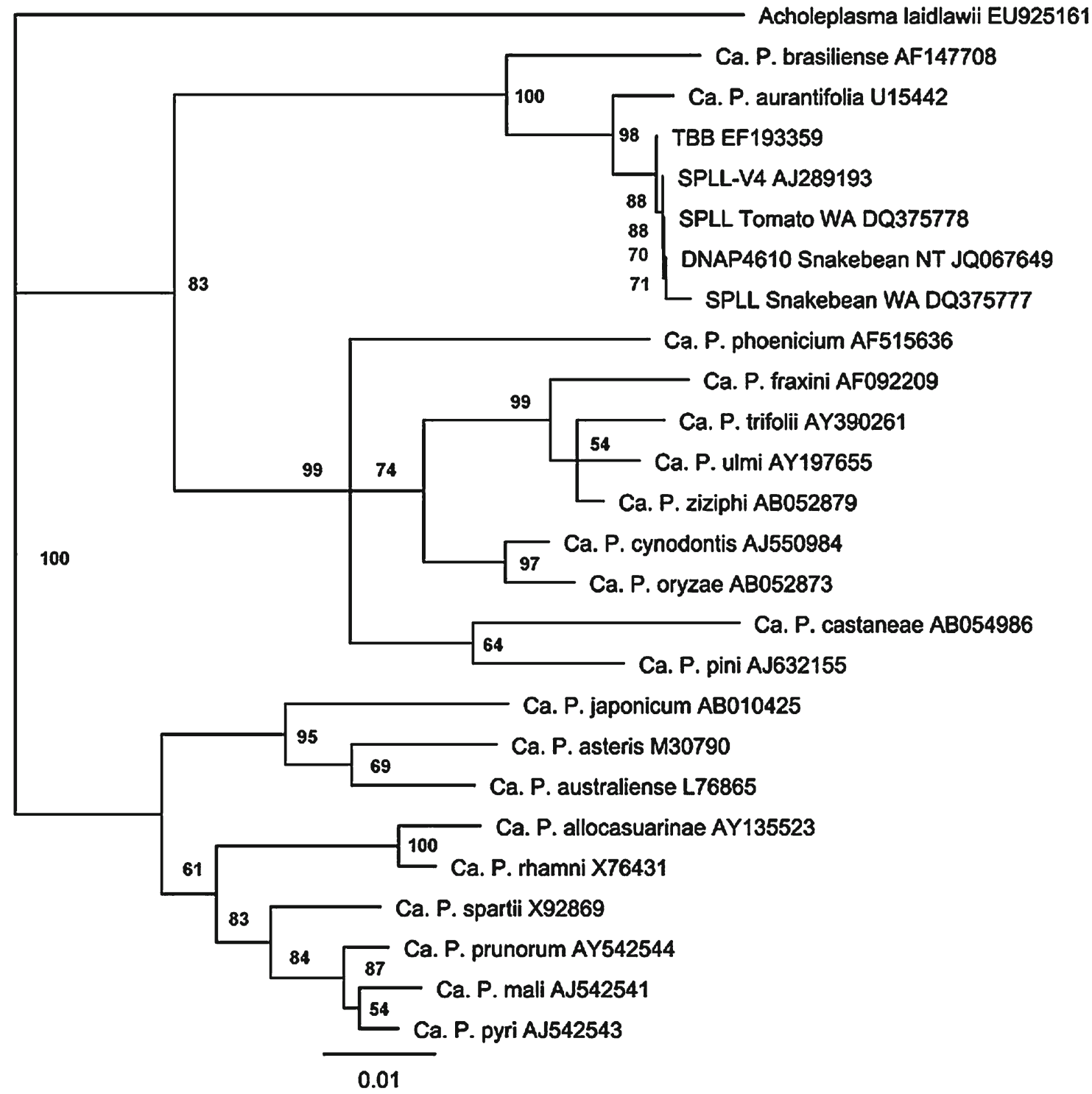

Fig. 2 Phylogenetic dendrogram of the 16S rRNA phytoplasma gene, generated using Geneious Pro software. The phytoplasma abbreviations "Candidatus Phytoplasma" represents each of the phytoplasma

argentata, Grylls 1979, Weintraub and Beanland 2006). Orosius lotophagorum ryukyuensis has been shown to transmit the phytoplasma associated with little leaf and phyllody symptoms on Ipomoea plebeia (bellvine) in Australia (Behncken 1984) and the one associated with witches' broom on I. batatas in Solomon Island (Jackson and Zettler 1983).

This is the first report of the SPLL-V4 phytoplasma in snake beans and Phyllanthus amarus in the NT. Phytoplasma-like symptoms were previously observed in snake bean plants in the field in the NT on eight occasions from 1994 to 2005 but occurring in low incidences (Department of Primary Industry and Fisheries, Plant Pathology Section unpublished records; B.D. Condé, pers. comm.). The symptoms expressed in the snake beans
16S groupings. The bootstrapped values were determined from 1,000 replicate trees. Acholeplasma laidlawii was used as the outgroup to root the tree

(Fig. 1) were similar to those described in Broome, Western Australia by Saqib et al. (2006).

Acknowledgments The authors thank Ben Stuckey (Northern Territory Herbarium) for the identification of Phyllanthus amarus; Lousia Cowie for the technical assistance, Barry D. Condé (DPIF) for the information provided; Karen Gibb (Charles Darwin University) for reference phytoplasma DNA and access to the Phytoplasma DNA database and the library staff at the Department of Resources, Berrimah Farm, for help in obtaining references.

\section{References}

APPD. Australasian Plant Pest Database (2011) available online at http://www.planthealthaustralia.com.au/go/phau/capacity-andcapability/information-support-systems/appd. Data accessed on 9th Dec 2011 
Behncken GM (1984) Orosius lotophagorum subsp. ryukyuensis (Hemiptera: Cicadellidae), a new vector of a little leaf disease in Australia. Australas Plant Pathol 13(3):35-36

Davis RIB, Schneider B, Gibb KS (1997) Detection and differentiation of phytoplasmas in Australia. Aust J Agric Res 48(5):535-544

De La Rue SJ, Schneider B, Gibb KS (1999) Genetic variability in phytoplasmas associated with papaya yellow crinkle and papaya mosaic diseases in Queensland and the Northern Territory. Australas Plant Pathol 28(2):108-114

Deng S, Hiruki C (1991) Amplification of 16S rRNA genes from culturable and nonculturable Mollicutes. J Microbiol Methods 14:53-61

Department of Primary Industry and Fisheries (2010) NT Plant Industries Profile 2009. Darwin. 12 p. (Information Sheet IS66) Available online at http://www.nt.gov.au/d/Content/File/p/ annualreport0506/IS66_2009_NT_plant_industry_profile.pdf

Drummond AJ, Ashton B, Buxton S, Cheung M, Cooper A, Duran C, Field M, Heled J, Kearse M, Markowitz S, Moir R, Stones-Havas S, Sturrock S, Thierer T, Wilson A (2011) Geneious v5.4. Available from http://www.geneious.com

Gibb KS, Padovan AC, Mogen BD (1995) Studies on sweet potato little-leaf phytoplasma detected in sweet potato and other plant species growing in Northern Australia. Phytopathology 85 (2):169-174

Grylls NE (1979) Leafhopper vectors and the plant disease agents they transmit in Australia. In: Maramorosch K, Harris KF (eds) Leafhopper Vectors and Plant Disease Agents. Academic, London, pp 179-214

Hill AV (1943) Insect transmission and host plants of virescence (big bud of tomato). J Counc Sci Ind Res Aust 16:85-90
Hogenhout SA, Oshima K, Ammar E-D, Kakizawa S, Kingdom HN, Namba S (2008) Phytoplasmas: bacteria that manipulate plants and insects. Mol Plant Pathol 9(4):403-423

IRPCM Phytoplasma/Spiroplasma Working Team-Phytoplasma taxonomy group (2004) 'Candidatus Phytoplasma', a taxon for the wall-less, non-helical prokaryotes that colonize plant phloem and insects. Int J Syst Evol Microbiol 54:1243-1255

Jackson GVH, Zettler FW (1983) Sweet potato witches' broom and legume little-leaf diseases in the Solomon Islands. Plant Dis 67 (9):1141-1144

Padovan AC, Gibb KS (2001) Epidemiology of phytoplasma diseases in papaya in Northern Australia. J Phytopathol 149:649-658

Saqib M, Bayliss KL, Jones MGK (2006) Identification of sweet potato little leaf phytoplasma associated with Vigna unguiculata var. sesquipedalis and Lycopersicon esculentum. Australas Plant Pathol 35(3):293-296

Schneider B, Cousin MT, Klinkong S, Seemüller E (1995) Taxonomic relatedness and phylogenetic positions of phytoplasmas associated with diseases of faba bean, sunhemp, soybean and eggplant. J Plant Dis Prot 102:225-232

Schneider B, Padovan A, De La Rue S, Eichner R, Davis R, Bernuetz A, Gibb K (1999) Detection and differentiation of phytoplasmas in Australia: an update. Aust J Agric Res 50(3):333-342

Streten C, Gibb KS (2006) Phytoplasma diseases in sub-tropical and tropical Australia. Australas Plant Pathol 35:129-146

Weintraub PG, Beanland L (2006) Insect vectors of phytoplasmas. Annu Rev Entomol 51:91-111

Wilson D, Blanche KR, Gibb KS (2001) Phytoplasmas and disease symptoms of crops and weeds in the semi-arid tropics of the Northern Territory, Australia. Australas Plant Pathol 30(2):159-163 